\title{
Wernicke's Encephalopathy, A Curable Cause of Acute Bilateral Vestibulopathy
}

\author{
Alfarghal Mohamad MD, AuD ${ }^{1 *}$ and Dhiaa El-Ebrahimy MD MSc ${ }^{2}$ \\ ${ }^{1}$ King Abdul Aziz Medical City-Jeddah, Saudi Arabia \\ ${ }^{2}$ Dhiaa M Yaseen Hearing \& Balance Center, Basrah, Iraq
}

Submission: April 26, 2018; Published: May 02, 2018

*Corresponding author: Alfarghal Mohamad, King Abdul Aziz Medical City-Jeddah, Saudi Arabia, Email: audio1972@gmail.com

Abbreviation: EFNS: European Federation of Neurological Societies; HIV: Human Immune Deficiency Virus; HPLC: High-Performance Liquid Chromatography; LARP: Left Anterior and Right Posterior Semicircular canal; MRI: Magnetic Resonance Imaging; RALP: Right Anterior and Left Posterior Semicircular canal; SCC: Semicircular canal; vHIT: Video Head Impulse Test; VOR: Vestibulocular Reflex; WE: Wernicke's Encephalopathy

\section{Introduction}

Carl Wernicke a German physician was the first to describe Wernicke's encephalopathy (WE) in 1881 [1]. WE are defined as an acute neurologic disorder resulting from thiamine (vitamin B1) deficiency [2]. WE is known to be common in alcoholics, but it was reported to be associated with conditions which cause nutritional deficiencies such as gastrointestinal malignancies, Hyperemesis Gravidarum, chemotherapy, HIV, prolonged therapeutic fasting, prolonged parenteral nutrition and bariatric surgery, anorexia nervosa and secondary to malnutrion due to poverty [3-6]. The classic symptom triad of WE consists of mental status changes, ophthalmoplegia, and gait ataxia, but research showed that this triad only presents in $16-19 \%$ of cases $[2,7,8]$. This has been taken into account by published diagnostic guidelines such as the EFNS guidelines, requiring only two out of four signs (dietary deficiencies, eye signs, cerebellar dysfunction, and either altered mental state or mild memory impairment [9]. Variety of neuro-opthlamological signs such as horizontal, vertical, and gaze-evoked nystagmus, abducens palsy, ophthalmoplegia) and internuclear-ophthalmoplegia could be found [10]. Nystagmus is the most commonly described sign, recent reports showed that bilateral severe impairment of lateral canal vestibule-ocular reflex is commonly associated with Wernicke's encephalopathy documented by bedside head impulse test, caloric testing and rotary chair testing [11-13]. The availability of video Head Impulse Test systems in the last few years made it possible to test the functions of the six semicircular canals [14-16]. The fact that afferents from horizontal canals relay mainly in medial vestibular nuclei and afferents from vertical canals relay mainly in lateral vestibular nuclei, and the fact that the medial vestibular nucleus is vulnerable to thiamine deficiency explains the selective impairment of vestibuleocular reflex of horizontal canals in cases of Wernicke's Encephalopathy [17,18]. Being a treatable cause of acute vestibulopathy, WE should be detected early using the vHIT and thiamine replacement should be initiated in a proper and rapid manner [19]. MRI brain can help in diagnosis of WE by showing the characteristic findings such as symmetrical alterations in the thalami, mammillary bodies, tectal plate, and periaqueductal area, but atypical alterations may also been seen $[18,20]$. Direct measurement direct of thiamine level in human blood is possible by a technique called HPLC. Adult normal range $(60-220 \mathrm{nM})$ .The blood sample should be taken before administration of thiamine and should be protected from light. However, normal thiamine levels can be found in cases of WE due to rare condition of thiamine transporter gene mutation [9,21-23]. Regarding the treatment of WE, there is no consensus on the optimal dose, form and duration of of thiamine treatment. Treatment with $200 \mathrm{mg}$ thiamine given intravenously three times daily until improvement of the symptoms and signs or until no further improvement could be obtained $[9,24,25]$.

\section{Case Report}

A 77-year-old man, with recent history of post-traumatic stress disorder after he had witnessed the sudden death of his son, the patient suffered loss of appetite, anorexia and vomiting over the last two months. He had no history of drinking alcoholics and he was in a good health until that incident. He presented to the specialized Hearing \& Balance clinic with unsteadiness, vertigo, blurring of vision during head movements, tingling in his four extremities, there was no concerns regards memory. On examination ; the patient was ataxic and unable to stand unsupported, there was horizontal gaze-evoked nystagmus, , vHIT showed bilateral selective severe lateral semicircular canal hypo functions (gain below 0.2 ) with compensatory saccades with normal VOR gain of vertical canals on RALP and LARP planes.MRI brain done and revealed unremarkable. Neurological examination showed no motor deficits. Serum vitamin B1 was 


\section{Global Journal of Otolaryngology}

assessed and the result showed decreased serum level. Vitamin $\mathrm{B}_{12}$ and $\mathrm{B}_{6}$ levels were of normal levels. Vitamin $\mathrm{B}_{1}$ (Thiamine) was given to the patient in a dose of $200 \mathrm{mg}$ intramuscular injection twice daily for two weeks. Gaze-evoked nystagmus disappeared at the 10th day of therapy. Ataxia improved after two weeks of treatment. vHIT was repeated after two weeks of treatment and showed marked recovery of the lateral canal VOR gain in both sides with disappearance of compensatory saccades Figure 1.

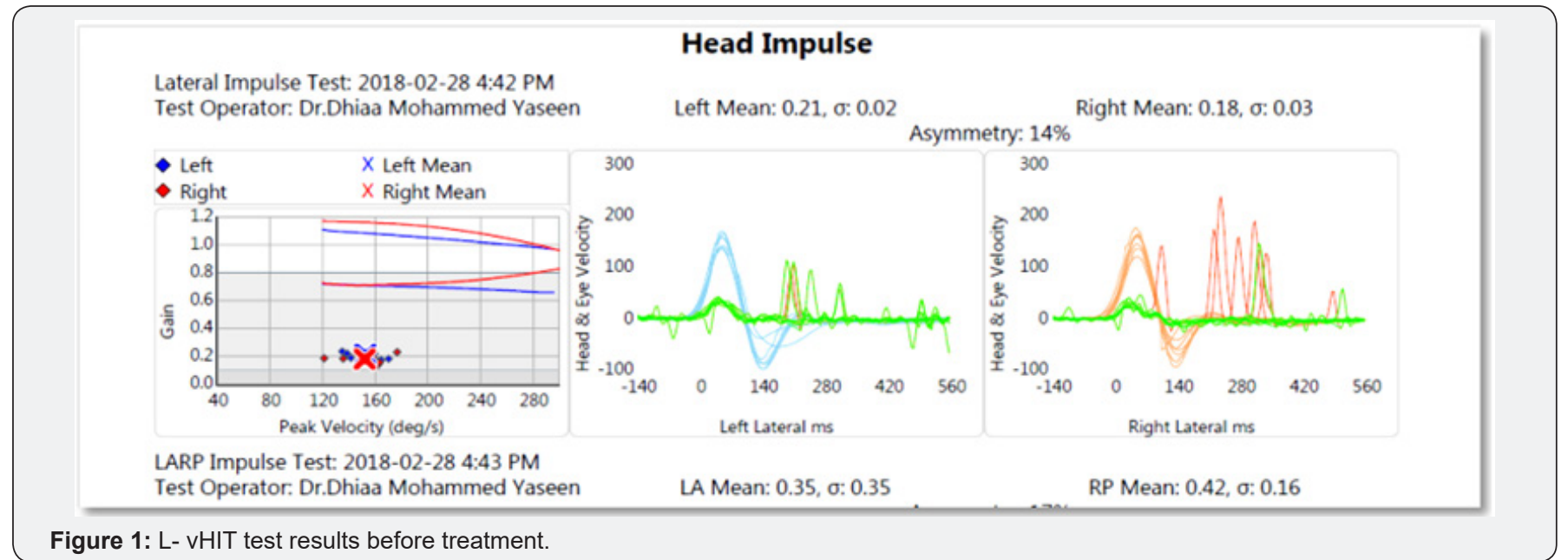

\section{Discussion}

The patient was presented with acute vestibular syndrome in the form of rapid onset but persistent unsteadiness and vertigo. The findings on clinical examination was suggestive of cerebellar involvement in the form of ataxia and gaze evoked nystgmus, testing the patient with vHIT revealed the characteristic finding of severe selective lateral canal hypofunction, which directed our attention to WE as the most probable diagnosis. The clear history of nutritional deficiency for two months in this case explains the thiamin deficiency. The low serum level of Thiamin supported the diagnosis of WE. The absent memory and mental changes as well as the absence of classical findings in MRI brain could be explained by the early stage of WE. The dramatic response to timely parental thiamin treatment confirmed the diagnosis. The findings in this case are in agreement with what has been recently reported in the literature. The use of vHIT for assessment of the six SCCs can enable the clinicians to easily detect the characteristic pattern of bilateral severe selective lateral canal hypofunction in cases of $\mathrm{WE}$, and hence the timely and prompt initiation of thiamin treatment. WE is a curable cause of bilateral vestibulopathy which should get more attention by clinicians Figure 2 .

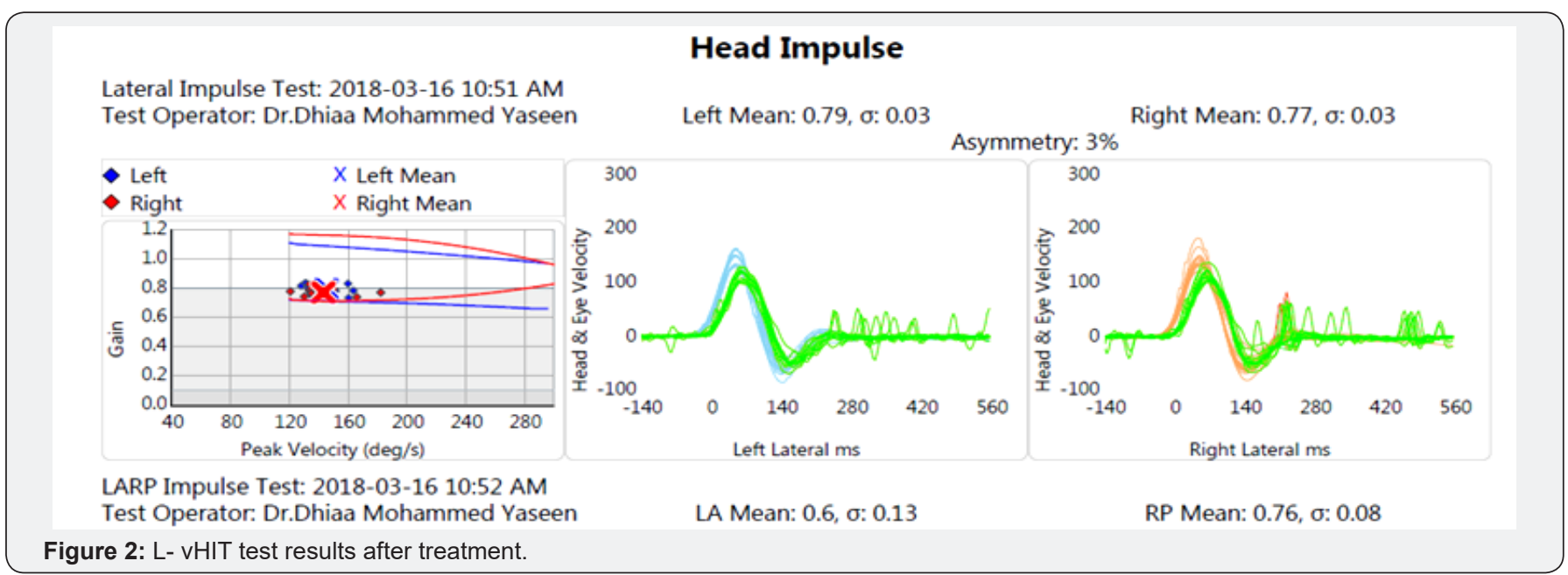

\section{References}

1. Wernicke C (1881) Die akute hamorrhagische Polioencephalitis superior. Lehrbuch der Gehirnkrankheiten fur Aerzte und Studierende Bd II. Kassel: Fischer Verlag pp. 229-242.

2. Harper CG, Giles M, Finlay Jones R (1986) Clinical signs in the WernickeKorsakoff complex: a retrospective analysis of 131 cases diagnosed at necropsy. J Neurol Neurosurg Psychiatry 49(4): 341-345.
3. Lindboe CF, Loberg EM (1989) Wernicke's encephalopathy in nonalcoholics: an autopsy study. J Neurol Sci 90(2): 125-129.

4. Foster D, Falah M, Kadom N, Mandler R (2005) Wernicke encephalopathy after bariatric surgery: losing more than just weight Neurology 65(12): 1987.

5. Al Fahad T, Ismael A, Soliman O, Khoursheed M (2006) Very Early Onset of Wernicke's Encephalopathy after Gastric Bypass. Obesity Surgery 16(5): 671-672. 
6. Santos Andrade C, Tavares Lucato L, da Grac M Morais Martin A, M Joaquina Marques-Dias, L Antonio Pezzi Portela, et al. (2010) Non-alcoholic Wernicke's encephalopathy: broadening the clinicoradiological spectrum. The British Journal of Radiology 83(989): 437-446.

7. Sechi G, Serra A (2007) Wernicke's encephalopathy: new clinical settings and recent advances in diagnosis and management. Lancet Neurol 6(5): 442-55.

8. Zuccoli G, Cruz DS, Bertolini M, Rovira A, Galluci M, et al. (2008) MR imaging findings in 56 patients with Wernicke encephalopathy: nonalcoholics may differ from alcoholics. Am J Neuroradiol 30(1): 171-176.

9. Galvin R, Brathen G, Ivashynka A, Hillbom M, Tanasescu R, et al. (2010) EFNS guidelines for diagnosis, therapy and prevention of Wernicke enceph-alopathy. Eur J Neurol 17(12): 1408-1418.

10. Kattah JC (2017) The spectrum of vestibular and ocular motor abnormalities in thiamine deficiency. Curr Neurol Neurosci Rep 17(5): 40 .

11. Ghez C (1969) Vestibular paresis: a clinical feature of Wernicke's disease. J Neurol Neurosurg Psychiatry 32(2): 134-139.

12. Halmagyi GM, Curthoys I (1988) A clinical sign of canal paresis. Arch Neurol 45: 737-739.

13. Furman JM, Becker JT (1989) Vestibular responses in Wernicke's encephalopathy. Ann Neurol 26(5): 669-674.

14. Macdougall HG, Mcgarvie LA, Halmagyi GM, Curthoys IS, Weber KP (2013) The video head impulse test (vHIT) detects vertical semicircular canal dysfunction. PLoS One 8: 61488.

15. Akdal G, MacDougall H, Chen L, Tanrıverdizade T, Halmagyi G (2016) Selective impairment of horizontal vestibulo-ocular reflexes in acute Wernicke's encephalopathy, Journal of the Neurological Sciences 365: 167-161.
16. Halmagyi GM, Chen L, Macdougall HG, Weber KP, Mcgarvie LA, et al. (2017) The video head impulse test. Front Neurol 8: 258.

17. Kattah JC, Guede C, Hassanzadeh B (2017) The medial vestibular nuclei, a vulner-able target in thiamine deficiency. J Neurol 265(1): 213-215.

18. Lee SH, Kim SH, Kim JM, Tarnutzer AA (2018) Vestibular Dysfunction in Wernicke's Encephalopathy: Predominant Impairment of the Horizontal Semicircular Canals. Front Neurol 9: 141.

19. Kattah JC, Dhanani SS, Pula JH, Mantokoudis G, Saber Tehrani AS, et al. (2013) Vestibular signs of thiamine deficiency during the early phase of suspected Wernicke encephalopathy. Neurol Clin Pract 3(6): 460468.

20. Torvik A, Lindboe CF, Rogde S (1982) Brain lesions in alcoholics. A neuropatho-logical study with clinical correlations. J Neurol Sci 56(3): 233-248.

21. Tallaksen CM, Bohmer T, Bell H, Karlsen J (1991) Concomitant determination of thiamin and its phosphate esters in human blood and serum by high-performance liquid chromatography. J Chromatogr 564(1): 127-136.

22. Lu J, Frank EL (2008) Rapid HPLC measurement of thiamine and its phosphate esters in whole blood.Clin Chem 54(5): 901-906.

23. Kono S, Miyajima H, Yoshida K, Togawa A, Shirakawa K, et al. (2009) Mutations in a thiamine-transporter gene and Wernickes-lik encephalopathy. N Engl J Med 360(17): 1792-1794.

24. Tallaksen C, Sande A, Bøhmer T, Bell H, Karlsen J (1993) Kinetics of thiamin and thiamin phosphate esters in human blood, plasma and urine after 50 mg intravenously or orally. Eur J Clin Pharmacol 44(1): 73-78.

25. Donnino MW, Vega J, Miller J, Walsh M (2007) Myths and misconceptions of Wernickes encephalopathy: what every emergency physician should know. Ann Emerg Med 50(6): 715-721.

\section{Your next submission with Juniper Publishers will reach you the below assets}

- Quality Editorial service

- Swift Peer Review

- Reprints availability

- E-prints Service

- Manuscript Podcast for convenient understanding

- Global attainment for your research

- Manuscript accessibility in different formats (Pdf, E-pub, Full Text, Audio)

- Unceasing customer service

Track the below URL for one-step submission https://juniperpublishers.com/online-submission.php 